\title{
Downregulation of Bradykinin Type 2 Receptor Expression in Cardiac Endothelial Cells during Senescence
}

\author{
Laura Nurmi $^{\mathrm{a}}$ Hanna M. Heikkiläa Heikki Vapaatalo ${ }^{\mathrm{b}}$ Petri T. Kovanen ${ }^{\mathrm{a}}$ \\ Ken A. Lindstedt ${ }^{\mathrm{a}}$ \\ ${ }^{a}$ Wihuri Research Institute and ${ }^{\mathrm{b}}$ Institute of Biomedicine, Pharmacology, University of Helsinki, Helsinki, Finland
}

\section{Key Words}

Senescence $\cdot$ Endothelial cells $\cdot$ Bradykinin type 2 receptor . Bradykinin type 1 receptor $\cdot$ GPR-100 - Angiogenesis . Hypertension

\begin{abstract}
Objectives: Bradykinin type 2 receptor (BK-2R) knockout mice develop microvascular dysfunction and cardiac hypertrophy. In aged human cardiac microvascular endothelium, dysfunction develops before heart failure symptoms. Since endothelial aging is an independent risk factor for cardiovascular disease, we aimed to clarify the role of kinin receptors in age-related endothelial senescence. Methods and $\boldsymbol{R e}$ sults: Using qRT-PCR, a downregulation of BK-2Rs during senescence of cultured human coronary artery endothelial cells (HCAECs) and rat cardiac microvascular endothelial cells (RCMECs) was observed. BK-2R downregulation was associated with a decreased cell proliferation rate, with a growth arrest phenotype and reduced angiogenic potential. By staining senescence-associated $\beta$-galactosidase, RCMECs from old spontaneously hypertensive rats (SHRs) were found to be significantly more senescent than those derived from age-matched WKY rats, albeit their telomere lengths were similar. Despite downregulation of BK-2Rs and BK-1Rs, a nov-
\end{abstract}

el family member GPR-100 was highly expressed in HCAECs throughout the culture period. Conclusions: Aging cardiac endothelial cells gradually lose their capacity to express BK$2 \mathrm{Rs}$, and this loss appears to be parallel with a loss of the angiogenic potential of the aging cells. Since RCMECs from hypertensive rats showed premature senescence, hypertension may predispose to cardiac dysfunction by accelerating endothelial aging.

Copyright $\odot 2011$ S. Karger AG, Basel

\section{Introduction}

We have previously reported significant changes in the expression levels of the two bradykinin receptors (BKRs), i.e. BK-1R and BK-2R, in cardiac tissue of spontaneously hypertensive rats (SHRs) during compensatory hypertrophy and heart failure. Thus, BK-2R expression was downregulated during the process, which leads to endstage heart failure, while the expression of BK-1R was upregulated [1]. Immunohistochemical studies of the heart revealed that the differential expression of BK-Rs appears to be primarily confined to endothelial cells of the small intramyocardial coronary vessels, whose dysfunction has been linked to other disease conditions, such as hyper-

\section{KARGER}

Fax +4161306 1234 E-Mail karger@karger.ch www.karger.com (c) 2011 S. Karger AG, Basel

1018-1172/12/0491-0013\$38.00/0

Accessible online at:

www.karger.com/jvr
Dr. Laura Nurmi

Wihuri Research Institute

Kalliolinnantie 4

FI-00140 Helsinki (Finland)

Tel. +358503043772,E-Mail lrnurmi@gmail.com 
tension [2], type 2 diabetes [3] and type 1 diabetes [4]. Indeed, myocardial ischemia due to dysfunction of the microvascular coronary endothelium [5] is a central pathophysiological feature leading to hypertrophic or dilated cardiomyopathy, and ultimately to manifest heart failure [6-8].

Since the BK-2R agonist, bradykinin, is a major regulator of endothelial cell function [9] and has been shown to prevent premature senescence of endothelial cells [10], downregulation of BK-2R may predispose to accelerated endothelial cell senescence. Similarly, cross-breeding of BK-2R knockout mice with Akita diabetes mice has led to significantly enhanced senescence in the cross-breeds, possibly as a result of increased oxidative stress [11]. Importantly, BK-2R knockout mice have been shown to develop cardiac hypertrophy accompanied by a microvascular deficit [12], and also by dilated cardiomyopathy [13]. Finally, cardiac hypertrophy [14] and impaired angiogenesis [15] occur during physiological aging.

In the present study, we aimed at clarifying the role of BK-2Rs in endothelial cell senescence. The role of BK-2Rs in endothelial senescence was studied in vitro using serial passaging of human coronary artery endothelial cells (HCAECs) and rat cardiac microvascular endothelial cells (RCMECs) using a culture system that mimics aging in vivo [16]. Since BK-2R expression is downregulated in SHRs during the process which leads to end-stage heart failure, we searched for signs of senescence of myocardial endothelium in RCMECs isolated from SHRs.

\section{Materials and Methods}

Culture of HCAECs

HCAECs were purchased from PromoCell GmbH (Heidelberg, Germany). The cells were grown in culture media (Endothelial Cell Growth Media MV, PromoCell GmbH) as recommended by the manufacturer. Briefly, the medium was changed every second day, and after 70-80\% confluency, the cells were subcultured (1:2) by using Detachkit-125 (PromoCell GmbH). HCAECs were cultured in a humified incubator at $37^{\circ} \mathrm{C}$ with a $5 \% \mathrm{CO}_{2}$ atmosphere with $21 \% \mathrm{O}_{2}$.

\section{Animals and Culture of RCMECs}

Male Wistar rats (Harlan, The Netherlands) were obtained from the Laboratory Animal Center of the University of Helsinki. Male Wistar-Kyoto outbred rats (WKY) were purchased from Taconic, Germantown, N.Y., USA, and outbred male SHRs of the Okamoto-Aoki strain were from Taconic M\&B, Bomholdtgaars, Denmark. When the (young) rats were 2 months old, they were designated 'young rats', and when they were 12-15 months old, they were designated 'old rats'. The rats were treated in accordance with institutional guidelines, which had been ap- proved by the Wihuri Research Institute Ethics Committee. RCMECs were isolated from rat myocardium and cultured as previously described with some modifications [17]. Briefly, rat myocardium was perfused to obtain RCMECs in the perfusate. Then the RCMECs were resuspended in M199 culture medium (Sigma Chemical Co., St. Louis, Mo., USA) which was supplemented with $20 \%$ serum derived from blood of the above-mentioned rat strains, $2 \mathrm{mM}$ L-glutamine (Lonza-Cambrex, Walkersville, Md., USA), $300 \mathrm{U} / \mathrm{ml}$ penicillin-streptomycin (LonzaCambrex) and $2.5 \mu \mathrm{g} / \mathrm{ml}$ amphotericin B (Sigma Chemical Co.). The RCMECs from young rats were seeded into T-25 bottles, and the RCMECs from old rats were seeded into smaller T-12.5 bottles because the numbers of cells obtained after perfusion of old rats' myocardia were significantly smaller than those obtained from young rats' myocardia. After 30 min of incubation, nonattached cells were washed away with the same medium as above and the attached RCMECs were cultured at $37^{\circ} \mathrm{C}$ under $5 \% \mathrm{CO}_{2}$ as described above. After 1 day, the culture medium was supplemented with 15\% FBS, 2 mM L-glutamine, $250 \mathrm{U} / \mathrm{ml} \mathrm{PS}$ and 2.5 $\mu \mathrm{g} / \mathrm{ml}$ amphotericin $\mathrm{B}$. The experiments were performed at passage 0 , except for the angiogenesis studies, which were performed at passage 1. Cells were divided using Detachkit-125 (PromoCell GmbH). The RCMECs isolated with this method were identified as microvascular endothelial cells based on their morphology, positive staining with Griffonia (Bandeiraea) simplicifolia lectin and uptake of DiI-labelled acetylated LDL (data not shown) $[17,18]$. Briefly, isolated cells stained positive with $G$. simplicifolia lectin (Sigma Chemical Co.), known to bind only to microvascular endothelium in rat myocardium, and negative for $\alpha$-smooth muscle actin (Dako, Glostrup, Denmark). In addition, they accumulated fluorescently labeled acetylated LDL only after overnight incubation, in contrast to HCAECs in which DiIAc-LDL accumulated within $4 \mathrm{~h}$.

\section{Quantitative RT-PCR}

Total RNA was isolated with RNeasy Plus Mini Kit (Qiagen, Valencia, Calif., USA), and $4 \mu \mathrm{g}$ of purified RNA was transcribed into cDNA using a Superscript preamplification system (Gibco Invitrogen, Paisley, UK) with oligo-dT primers (Promega, Madison, Wisc., USA). For real-time PCR, between 20 and 300 ng of RNA was used. For human samples, primers and probes were purchased from the Applied Biosystems Custom Taqman ${ }^{\circledR}$ Gene Expression Assay Service (Applied Biosystems, Foster City, Calif., USA); Endogenous control ACTB (forward 5'-CCCCGCGAGCACAGA-3'; reverse 5'-GCGGCGGGTGTGGA-3') and (FAMlabeled MGB probe $5^{\prime}$-CCTTTGCCGATCCGCC-3'). BK-2R (forward 5'-CCCACCACGGCCTCTT-3'; reverse 5'-GGGCAAAGGTCCCGTTAAGA-3') and (FAM-labeled MGB probe $5^{\prime}$ TCAGCGCCGACATGC-3'). BK-1R primers and MGB probe (forward 5'-ACTTCTTTGCCTTCCTGGAATTCTT-3'; reverse 5'-AGGTCAATG AAGTCCTCCCAAAAG-3') and (FAM-labeled MGB probe 5'-CAGCCTCGGACTGCTT-3'). GPR-100 primer and probe and rat assay endogenous control ACTB were purchased from the Applied Biosystems Assays-on-demand Taqman ${ }^{\circledR}$ Gene Expression products. BK-2R primers and probe were designed according to accession No. NM_173100: sense primer: 5'-CAAATGCACTGTTCTTG-3'; antisense: 5'-CAGTTGACCTCTGAAAAG-3'; probe:5'-FAM-CACAGCCTCTCTGGGCATTGAAABHQ1-3'. BK-1R primers were designed according to the accession No. NM_030851: sense primer: 5'-AGGGTTCGTC- 
ATCACTAT-3'; antisense: 5'-AGGTAGATTTCCGCTATG-3'. Real-time PCR was accomplished with $400 \mathrm{nM}$ forward and reverse primers and a $200-\mathrm{nM}$ probe.

Real-time PCR analyses were performed using a Taqman ${ }^{\circledR}$ Universal Master Mix (Applied Biosystems) in 25- $\mu$ l reaction volumes and analyzed with an ABI Prism 7500 Sequence Detection System (Applied Biosystems) using a two-step program consisting of $15 \mathrm{~s}$ at $95^{\circ} \mathrm{C}$ and $1 \mathrm{~min}$ at $60^{\circ} \mathrm{C}$ for 40 cycles, with the exception of rat BK-2R that was performed for $1 \mathrm{~min}$ at $58^{\circ} \mathrm{C}$. Data were analyzed by relative quantification with sequence detection software (Applied Biosystems 7500 Real-Time PCR system, Version 1.2.1) according to the manufacturer's instructions.

Relative expression differences between kinin receptors in HCAEC culture were expressed as an abundance of mRNA between GPR-100 and BK-receptors in different passages using ACTB endogenous control. The lowest relative expression level of GPR-100 was used as a standard, and relative expression levels of $\mathrm{BK}-2 \mathrm{R}$ and $\mathrm{BK}-1 \mathrm{R}$ were proportioned and calculated with the help of CT differences, which were further changed to relative mRNA differences. The data were expressed as relative mRNA abundances.

\section{Senescence Assays}

Genomic DNA was extracted from HCAECs using the QIAamp DNA Micro Kit (Qiagen) according to the manufacturer's instructions. TeloTAGGG telomere length assay (Roche Diagnostics $\mathrm{GmbH}$, Mannheim, Germany) was used according to the manufacturer's instructions. Briefly, $1.0 \mu \mathrm{g}$ (human) and $1.5 \mu \mathrm{g}$ (rat) of genomic DNA was digested with HinfI and RsaI, increasing the incubation time over night at $37^{\circ} \mathrm{C}$ with rat gDNA. The DNA was subjected to Southern blot analysis using a labeled telomere-specific probe.

The amount of mitochondrial DNA (mtDNA) was determined from HCAECs (fig. 2b). Genomic DNA was extracted from HCAECs using the QIAamp DNA Micro Kit (Qiagen) according to the manufacturer's instructions. For PCR analysis, $50 \mathrm{ng}$ of gDNA was used as both mtDNA and $\beta$-globin analysis. Assay for mtDNA amplification was designed according accession No. NC_001807: sense, 5'-TCTATCACCCTATTAACCACTCACGG-GAGC-3' and anti-sense, 5'-GGATACAGTTCACTTTAGCTACCCCCAAGTG-3', resulting in a PCR product of $16.5 \mathrm{~kb}$ of mtDNA which was amplified in 23 cycles. Control $15.2 \mathrm{~kb}$ of the $\beta$-globin gene was amplified in 30 cycles. Primers were designed according to accession No. NG_000007: sense 5'-TTAAGGTGAGAAGGCTGGAGGTGAGATTC-3' and anti-sense, 5'-AAGCATTTATGAGGTCAGCGTAGGGTCTC-3'. The PCR protocol included a 30-second denaturation step followed by $23-30$ cycles $\left(98^{\circ} \mathrm{C}\right.$ denaturation for $10 \mathrm{~s}$ and $72^{\circ} \mathrm{C}$ annealing and extension step for 8 min $15 \mathrm{~s}$ ). Samples were amplified by Phusion ${ }^{\mathrm{TM}}$ Hot Start High-Fidelity DNA Polymerase (Finnzymes, Woburn, Mass., USA). The blots were quantitated with a Gel Doc 2000 gel documentation system (Bio-Rad, Hercules, Calif., USA).

Staining of the senescence-specific $\beta$-galactosidase was performed as earlier described [19]. Briefly, cells were washed in PBS, fixed for $3 \mathrm{~min}$ (room temperature) in 3\% paraformaldehyde (Fluka AG, Buchs, Switzerland) and incubated at $37^{\circ} \mathrm{C}$ (without $\mathrm{CO}_{2}$ ) for $24 \mathrm{~h}$. Tissue sections $(5 \mu \mathrm{m})$ were fixed for $5 \mathrm{~min}$ in $2 \%$ formaldehyde $/ 0.2 \%$ glutaraldehyde at $4{ }^{\circ} \mathrm{C}$, washed and incubated for 8 days with fresh prewarmed senescence-associated $\beta$-galactosidase (SA- $\beta-\mathrm{Gal})$ staining solution.

Bradykinin Receptors and Senescence

\section{Angiogenesis Assay}

RCMECs were isolated as described above from 3 young (2 months) and 4 old (12-15 months) rats. When the cells had reached confluence or had failed to grow during a period of 14 days, they were counted and seeded at $5 \times 10^{3}$ RCMECs/well on BD Matrigel TM Matrix Basement Membrane (BD Biosciences, Bedford, Mass., USA) in triplicate. Matrigel was placed into the lower chambers of an angiogenesis u-slide (Applied BioPhysics, Troy, N.Y., USA) and prepared according to the manufacturer's instructions. Endothelial tube formation was observed after $24 \mathrm{~h}$. Angiogenesis was allowed to proceed for 13 days at $37^{\circ} \mathrm{C}, 5 \% \mathrm{CO}_{2}$ and M199 rat medium was changed once a day. Cells were photographed (with a CCD camera) each day between 8 and 13 days of culture using an imaging system (SPOT RT with spot advanced software, version 4.1; Diagnostic Instruments, Sterling Heights, Mich., USA) with a camera connected to a Nikon microscope (Model C-DSS230, Nikon, Tokyo, Japan). Sample wideness, maximal unitary length and branching were analyzed using the Image-Pro Plus (6.2) image analysis system (Media Cybernetics, Silver Spring, Md., USA).

\section{Statistics}

Statistical analyses were performed using the Mann-Whitney $\mathrm{U}$ test. $\mathrm{p}$ values $<0.05$ were considered statistically significant.

\section{Results}

\section{Expression of Kinin Receptors, $B K-2 R, B K-1 R$ and} GPR100 during Passaging of HCAECs

HCAECs cultured from the third (p3) to the fifth (p5) passage showed a significant downregulation in the mRNA expression levels of BK-2Rs (fig. 1a). After reaching a quiescent phenotype (fig. 1b), telomeres were not shortened more than $30 \%$ of their length at the end of the HCAECs' life span (fig. 1c). In parallel to downregulation of BK-2R expression (fig. 2a), mtDNA was found to accumulate (fig. $2 \mathrm{~b}$ ) with no changes observed in $\beta$-globin (fig. 2b), suggesting an increasing level of oxidative stress [20]. GPR-100 (GPCR142), which binds BK and kallidin with high affinity [21], showed markedly higher expression levels than the other two BK-Rs, and remained constitutively expressed throughout the HCAECs' life span (fig. 1a, 2a). The mRNA expression level of BK-1Rs was decreased from $\mathrm{p} 3$ to $\mathrm{p} 4$ (fig. 1a) but was transiently increased at the end of the HCAECs' life span (fig. 1a, 2a). In parallel to this process, the growth rate of the HCAECs, i.e. time interval for the HCAECs to reach confluence, was prolonged from 4 days to 8-10 days (fig. 1b). Similarly, HCAECs that were obtained from males of different ages showed a trend towards an age-dependent decrease in BK2R already at $\mathrm{p} 4$ (fig. 3). These data of the donor, age and gender, give evidence supporting the relationship between senescence and BK-2R expression in in vitro experiments. 

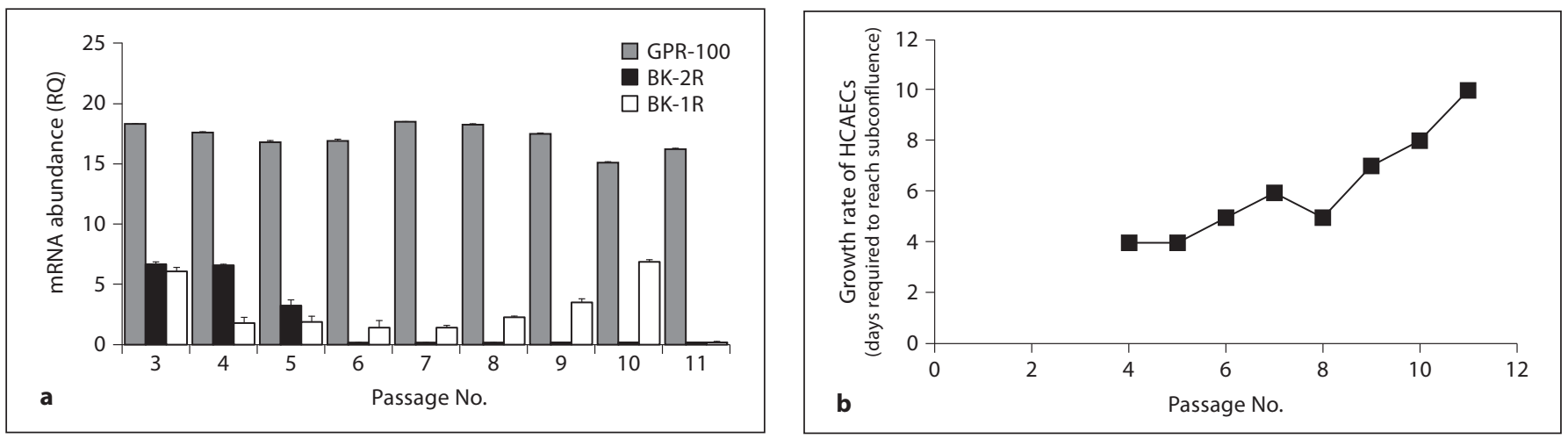

Fig. 1. Expression of kinin receptors in HCAECs from a 53-yearold male donor related to telomere lengths. a Relative expression rates of BK-2R, BK-1R and GPR-100 $(n=3)$ at different cell passages (p). $\mathbf{b}$ The rate of cellular growth is expressed as days per passage. c Telomere lengths of DNA isolated from HCAECs at different passages.

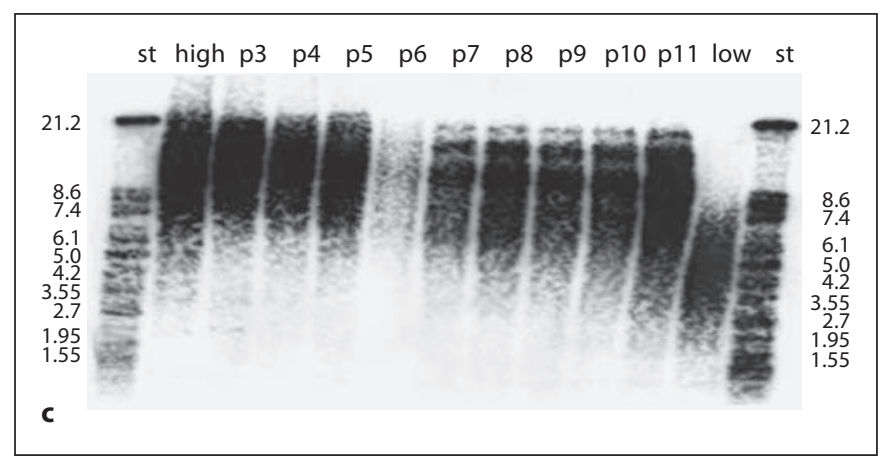

Fig. 2. Expression of kinin receptors in HCAECs from a 48-year-old male donor related to mtDNA amount. a Relative expression rates of BK-2R, BK-1R and GPR100 at different cell passages. The rate of cellular growth is expressed as days per passage. b Upper panels show the quantified content of mtDNA compared to endogenous marker $\beta$-globin gene in each passage and the lower panels show typical agarose gels.
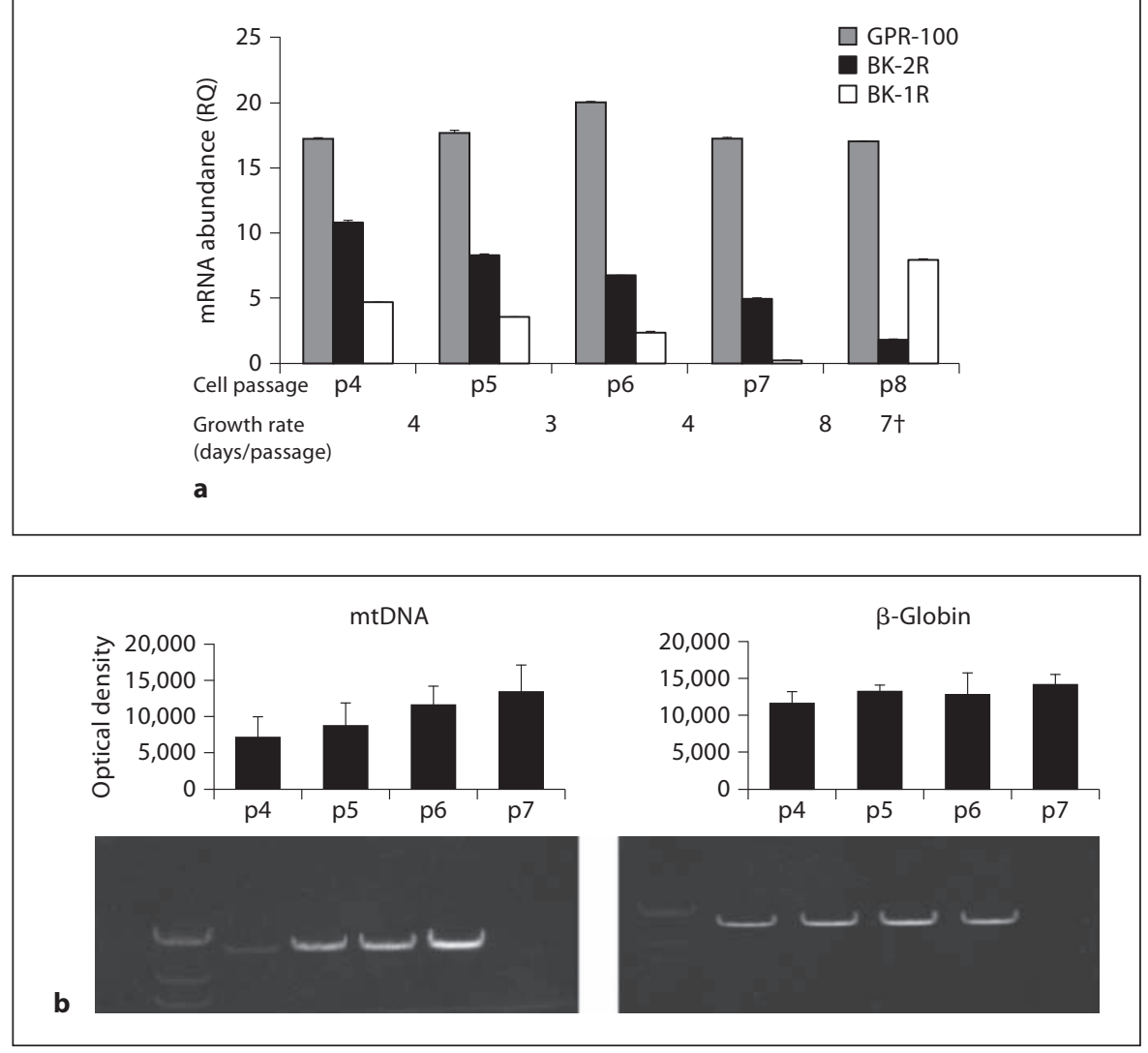


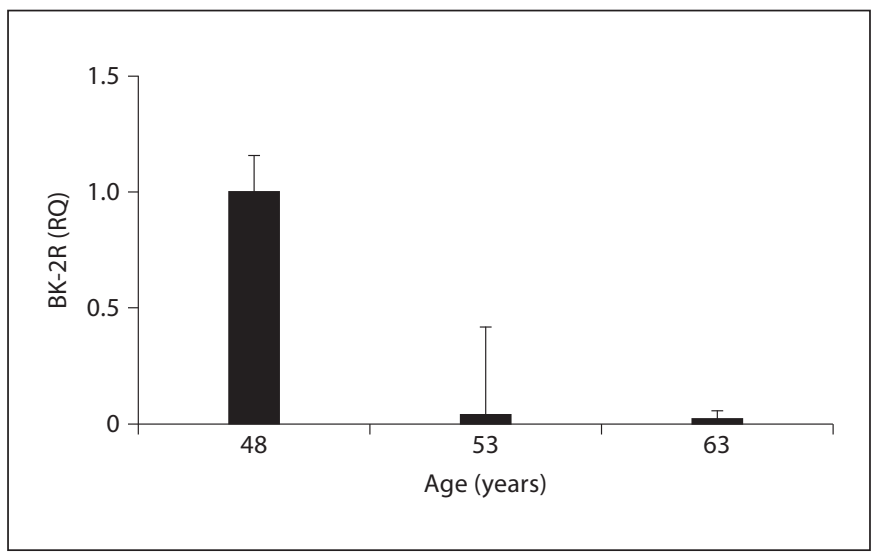

Fig. 3. Age-dependent decrease in BK-2R expression. HCAECs obtained from 3 males of different ages showed a trend towards an age-dependent decrease in BK-2R expression at $\mathrm{p} 4$.
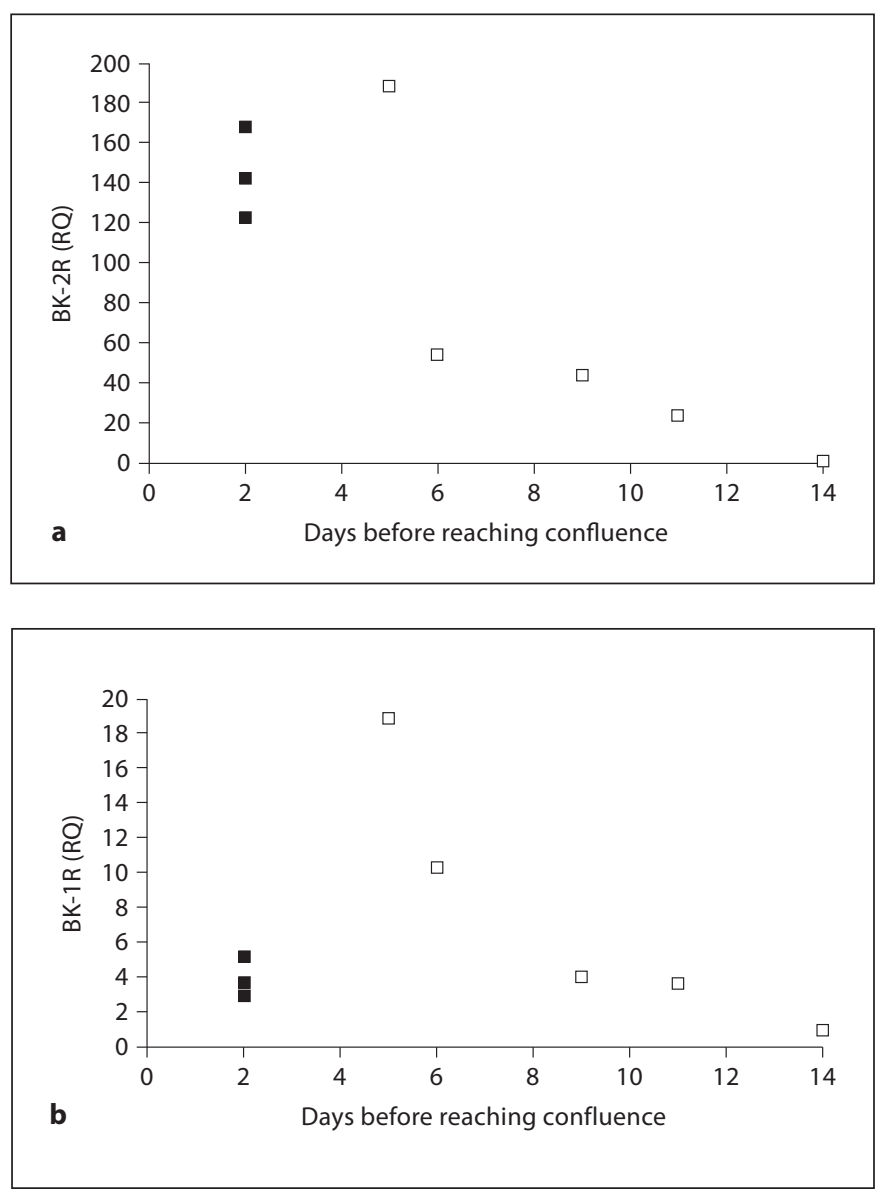

Fig. 4. Expression of kinin receptors in cultured RCMECs. RCMECs were isolated from young $(\square, \mathrm{n}=3)$ and old $(\square, \mathrm{n}=5)$ rats. a Among old rats, expression of BK-2Rs was reduced, correlating inversely to the time before reaching confluence. $\mathbf{b} \mathrm{BK}-1 \mathrm{R}$ expression was similar in young and old rats.

Bradykinin Receptors and Senescence

\section{Expression of Kinin Receptors in RCMECs}

By comparing isolated RCMECs from young (2 months of age) and old (12-15 months of age) rats, major differences in RNA expression and cell proliferation were observed. RCMECs from young rats showed high BK-2R expression and RCMECs from old rats showed low BK-2R expression (fig. 4a). Moreover, according to visual inspections, the time during which the RCMECs remained quiescent after seeding, i.e. before they recovered and began to proliferate (ranging from 2 days in cells from young rats to 5-14 days in cells from old rats), correlated inversely with the BK-2R expression levels (fig. 4a). In contrast, $\mathrm{BK}-1 \mathrm{R}$ expression was similar in RCMECs derived from either young or old rats (fig. 4b).

RCMECs isolated from young rats (2 months of age) markedly expressed BK-2Rs, reached confluence within 2 days of culture and had a high angiogenic potential, when measured as volume, organization and branching of the forming vessels (fig. 5a-c, 6). BK-2R expression of RCMECs of 1 old rat (12-15 months of age) recovered in 5 days. Still, its angiogenic potential was reduced compared to the RCMECs of younger rats except in part for branching (fig. 5d, 6). In contrast, RCMECs that were isolated from old rats and did not show BK-2R expression had a similar quiescent phenotype, did not reach confluence within 14 days of culture and showed a significantly reduced angiogenic potential (fig. $5 \mathrm{e}-\mathrm{g}$, 6). Thus, these results indicate that during aging cardiac endothelial cells gradually lose their BK-2R expression and angiogenic potential before finally becoming quiescent.

\section{Premature Senescence of Cardiac Endothelial Cells}

To evaluate whether similar premature senescence can be observed in human hypertension and heart failure, left ventricles of hypertensive patients with end-stage heart failure were assayed for senescence-associated $\beta$-galactosidase. As shown in figure $7 \mathrm{a}$, regional positive $\beta$-galactosidase staining was observed in such failing myocardium, but not in healthy control myocardium (fig. $7 \mathrm{~b}$ ). We also compared $\beta$-galactosidase staining of RCMECs isolated from SHRs and from age-matched WKY rats, and found that the former stained more intensively than the latter $(\mathrm{p}<0.05)$ (fig. 7c-e). However, the lengths of telomeres were similar in RCMECs from both the old SHR and old WKY rats, although they were shorter than in the RCMECs of a 6-month-old control rat (fig. 7f). These findings are compatible with the notion that, in vivo, myocardial endothelial cells of SHRs show hypertension-induced accelerated senescence. 


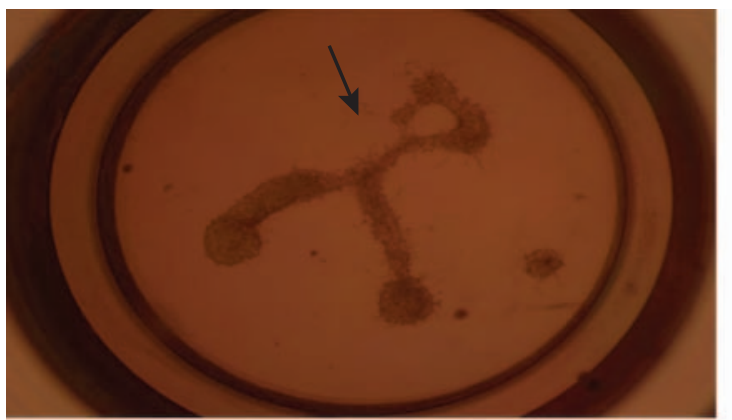

a

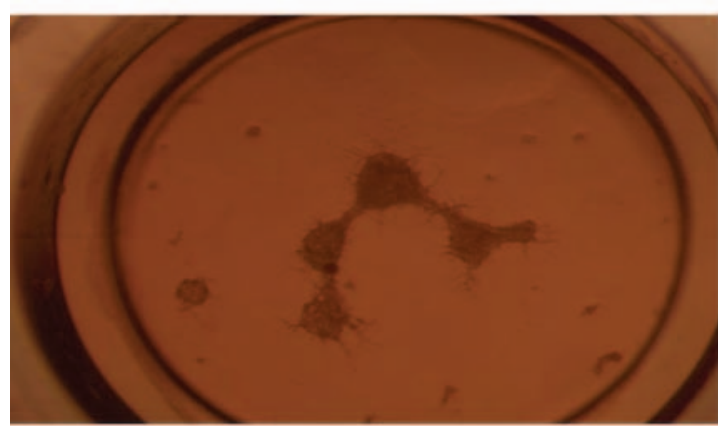

b

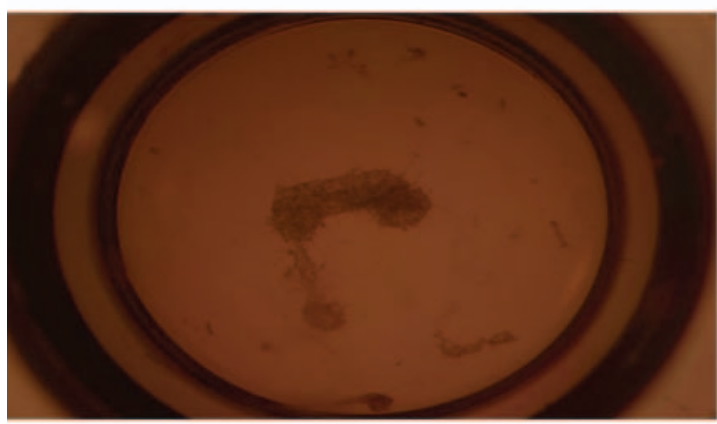

C

RCMECs from young rat BK-2R mRNA+

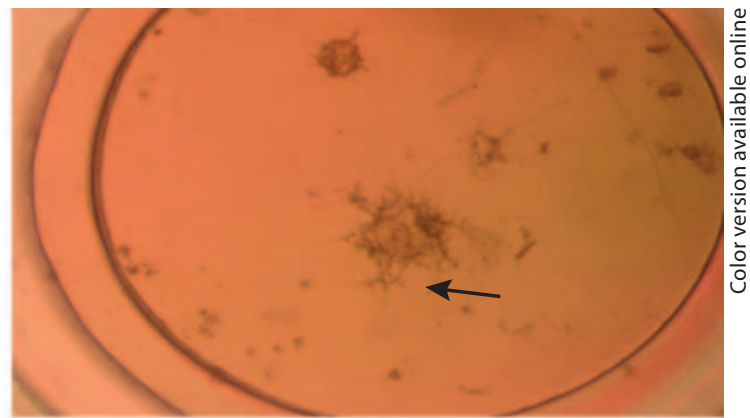

d $\quad$ RCMECs from old rat BK-2R mRNA+

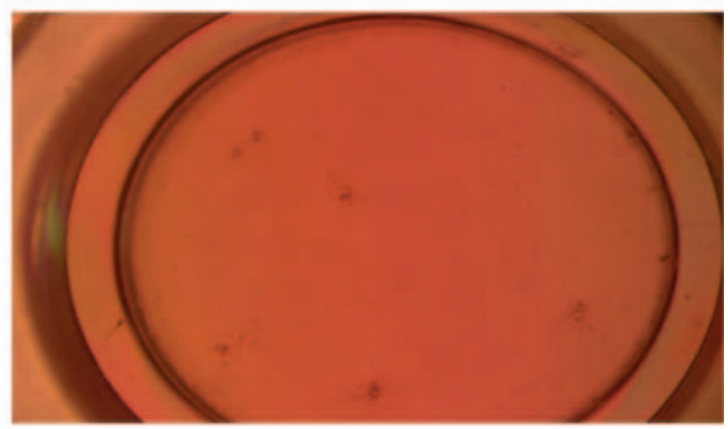

RCMECs from old rat BK-2R mRNA-

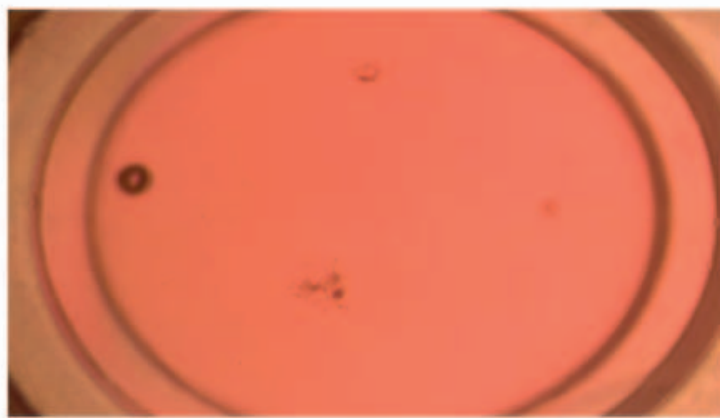

f RCMECs from old rat BK-2R mRNA-

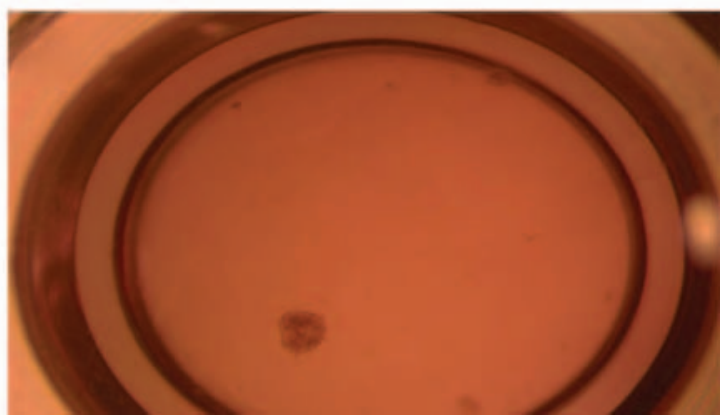

g

RCMECs from old rat BK-2R mRNA-

Fig. 5. Angiogenic potential of RCMECs cultured on matrigel. RCMECs isolated from young were cultured 13 days on BD matrigel. a-c RCMECs from young rats with both high BK-2R expression (mRNA+) and angiogenetic potential. d RCMECs from an old rat with BK-2R expression (mRNA+) but reduced angiogenetic potential of RCMECs. e-g RCMECs from old rats with no BK-2R expression (mRNA-) and very low (e, $\mathbf{f}$ ) or no (g) angiogenetic capacity. Arrows indicate branching points. 

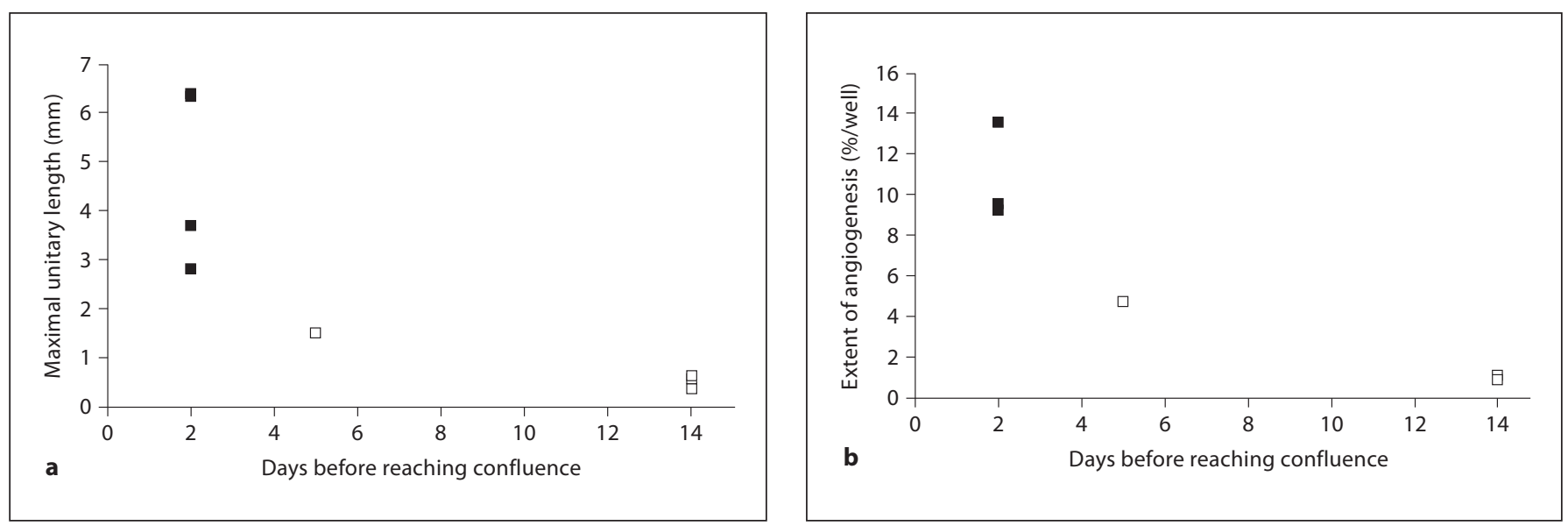

Fig. 6. Quantitation of angiogenetic capacity as a function of days before the cells reached confluence. Data from angiogenesis study shown in figure 5 were analyzed by Image-ProPlus. $\square=$ Young rats ( $\mathrm{n}=3) ; \square=$ old rats $(\mathrm{n}=4)$. a Maximal unitary length. b Extent of angiogenesis. c The branching capacity was calculated when the branch exceeded $0.05 \mathrm{~mm}$ (14 pixels).

\section{Discussion}

In the present study, we have investigated the role of $\mathrm{BK}-2 \mathrm{R}$ expression in premature aging of intramyocardial microvascular endothelial cells, a process that according to present knowledge may predispose to heart failure [22-24]. Our main results show that the senescence process of cardiac endothelial cells is associated with downregulation of BK-2R expression. The present data suggest that dysregulation of BK-2Rs in aging endothelial cells may be one significant component in the heart failure-related process of premature aging of vascular endothelial cells.

Senescence is equivalent to a state of permanent cell growth arrest. Senescence is also induced by stress or injury and affects cell function, including the loss of bioavailable nitric oxide generation. In previous studies, BK2Rs have been regarded as cardioprotective $[25,26]$ since their second messengers, e.g. nitric oxide $[9,27,28]$, pros-

tacyclin [29], and endothelium-derived hyperpolarizing factor $[30,31]$ tend to support vital heart functions, and loss of BK-2Rs has since been linked to several cardiovascular disorders. The present results show that, in parallel to downregulation of BK-2Rs, mtDNA accumulates in a process that has been linked to mitochondrial malfunction [32] and to increased oxidative stress [20, 33-35]. Previous results have also linked age-dependent malfunction of both rat and human endothelial cells with an increase of oxidative stress $[36,37]$ as well as with impaired responses of bradykinin in aged human vasculature [38]. These findings are in agreement with our present in vitro and ex vivo results. The downregulation of BK-2R expressions occurs in parallel with coexisting functional impairment during ongoing processes of senescence in cardiac endothelial cells. Moreover, our results with endothelial cells isolated from young and old animals as well as from control and hypertensive rats predict that a process of senescence similar to that observed 


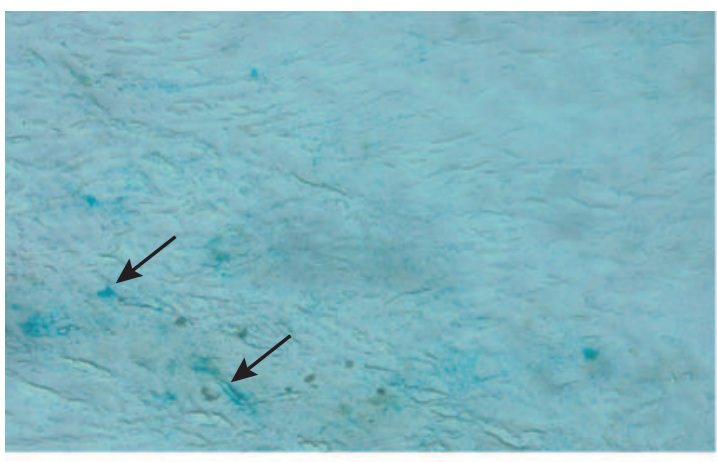

a Human myocardium with end-stage heart failure

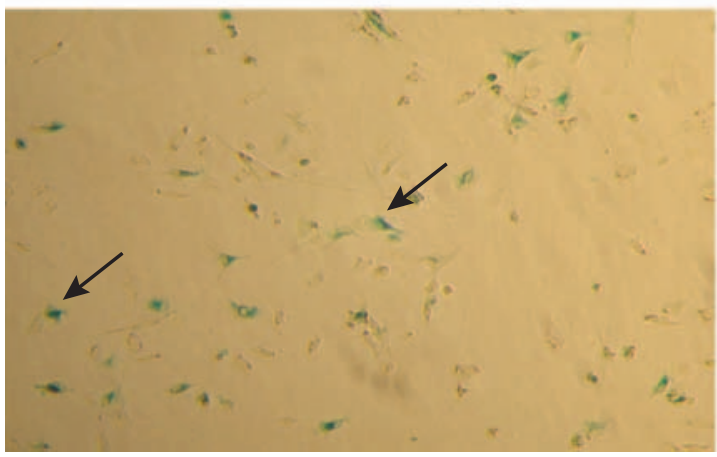

c

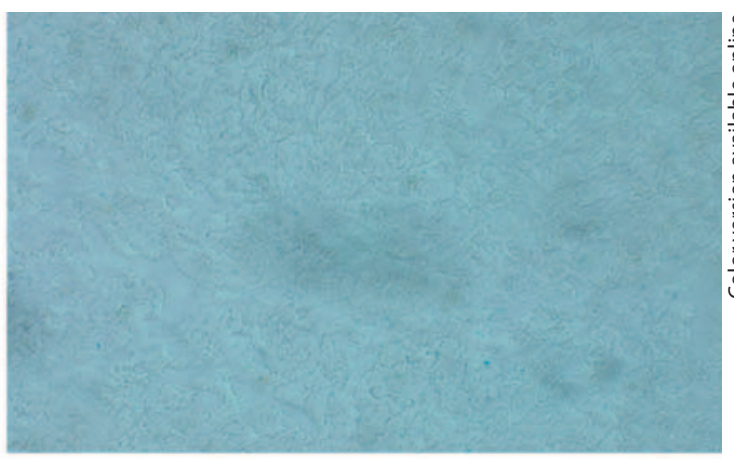

b Human control myocardium

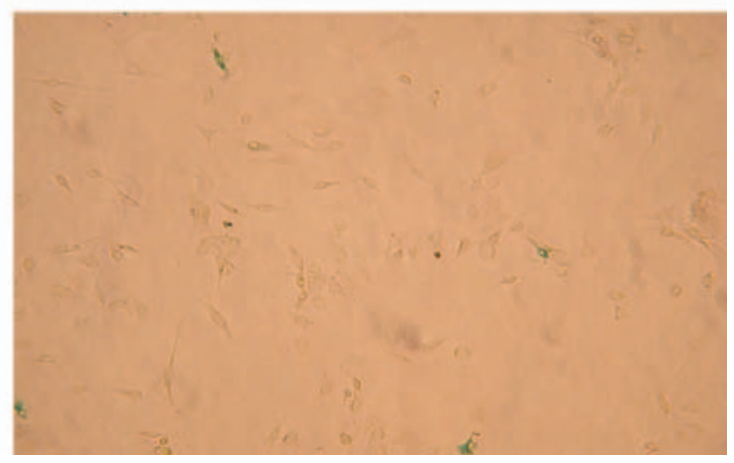

WKY

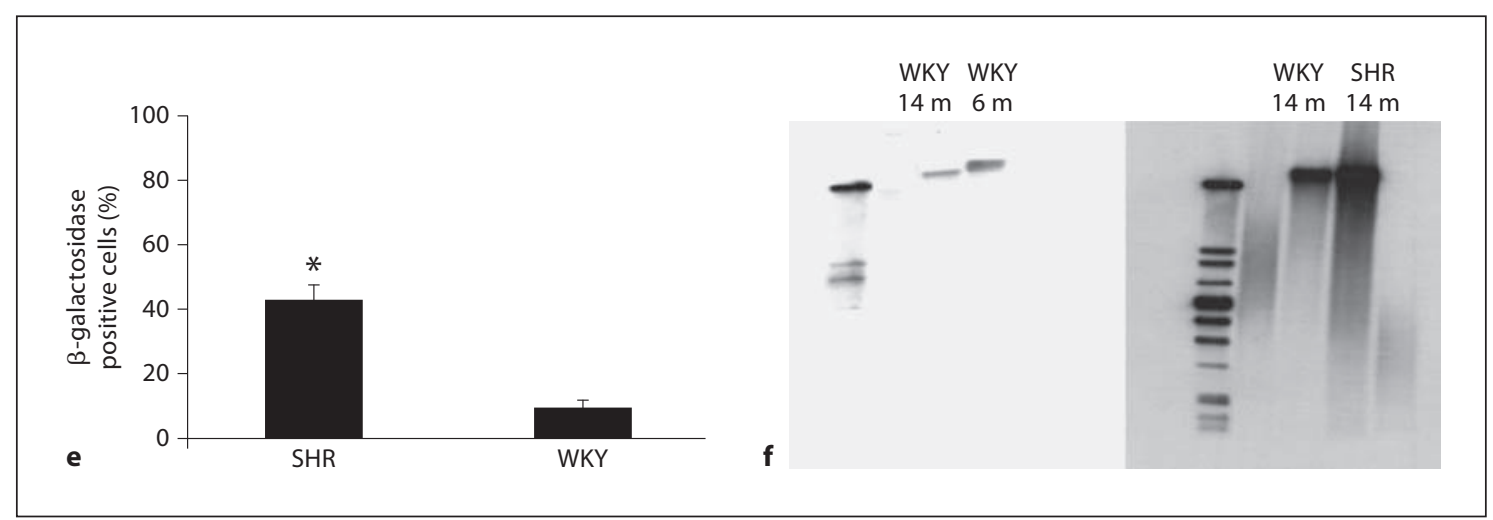

Fig. 7. Determination of senescence-associated $\beta$-galactosidase in cardiac endothelial cells. SA- $\beta$-galactosidase staining (positive areas denoted with arrows, $\mathrm{n}=1$ ). a Left ventricular tissue from human heart with end-stage heart failure. b Left ventricular tissue from control human heart. c RCMECs from an old (14 months) SHR. d RCMECs from an old (14 months) WKY rat. e Quantitation of SA- $\beta$-galactosidase-positive RCMECs from SHR and WKY ( $n=1$ calculated from 5 randomly chosen windows). ${ }^{*} \mathrm{p}<0.05$. $\mathbf{f}$ Telomere lengths from SA- $\beta$ galactosidase-stained 14-month WKY and SHR RCMECs ( $\mathrm{m}=$ months). RCMECs from 6-month WKY were used as a control.

in cultured endothelial cells can also be seen in vivo. This suggests that the aging process is basically identical within cardiac endothelial cells, but the time of onset varies depending on external factors, such as mechanic stimulus, that will accelerate proliferation and premature senescence [39-41].
In addition to dysfunction of the microvascular myocardial endothelium, impairment of myocardial angiogenesis plays a central role in the pathogenesis of both hypertension- and diabetes-induced adverse cardiovascular remodeling and heart failure [42]. Since both BK$2 \mathrm{Rs}$ and BK-1Rs have been shown to play a role in neovas- 
cularization [43-45], a reduction in their expressions during the senescence process is likely to attenuate the process of angiogenesis. Indeed, in parallel to the gradual transfer of cardiac microvascular endothelial cells towards a growth arrest phenotype, we observed impairment in their potential to induce angiogenesis in vitro, a phenomenon that has also been described in vivo in aging human hearts [46]. However, despite the lack of mitotic activity, particular metabolic pathways may be highly active in senescent cells as they express high levels of selective genes that do not correlate with cell cycle arrest [47]. Endothelial dysfunction with altered relaxation and impaired neovascularization has been shown to contribute to functional decompensation of pressure-overload cardiac hypertrophy [48], and may thus be due to aging and accelerated stress-induced premature senescence of the endothelial cells followed by subsequent formation of a growth arrest phenotype with lost angiogenic potential. In the rat, angiotensin II has been shown to regulate $\mathrm{BK}-2 \mathrm{R}$ expression, possibly via $\mathrm{p} 53$ activation [49-51]. Our results give further support to the involvement of p53 in senescence, inhibition of angiogenesis and induction of heart failure [48]. Our present results, which show that, despite marked downregulation of the BK-2Rs, GPR-100 was strongly expressed in senescent HCAECs, support the above notion. Under physiological conditions, however, the role of GPR-100 as a mediator of BK signaling is questionable since the agonist potency of BK for GPR-100 activation is 100 -fold lower than for BK-2R [52]. The strong expression of GPR-100 in high-passage cultured cardiac endothelial cells with a downregulated BK-2R expression would suggest that the BK-induced en- dothelium-mediated cardioprotective effects are partially me-diated via GPR-100 also under pathological conditions $[53,54]$. In addition, GPR-100 also mediates the effects of relaxin-3 [55, 56], which may also exert cardioprotective effects in heart failure [57]. Finally, the observed increase in BK-1R expression both in the beginning and the end of the life span of cultured HCAECs suggests that BK-1Rs might have a dual role in the progression of human endothelial cell senescence.

In summary, the kinin receptors BK-2R and BK-1R seem to play a role in the onset and progression of senescence in cardiac endothelial cells. Moreover, our present results suggest that different kinin receptors are differentially expressed at distinct time points during the process of human endothelial cell senescence. Future experiments will aim at clarifying the molecular mechanisms involved in the differential expression of these kinin receptors during senescence of endothelial cells in the physiologically or pathologically aging heart.

\section{Acknowledgements}

We thank Minna Loponen for help with statistics, Mikko Mäyränpää $\mathrm{MD}, \mathrm{PhD}$, for collecting human cardiac samples, and Jani Lappalainen for excellent methodological advice with PCR. Elina Kaperi, Mari Jokinen, Jaana Tuomikangas, Maija Atuegwu, Jarmo Koponen and Suvi Sokolnicki are thanked for their excellent technical assistance. During the preparation of the manuscript Laura Nurmi held a grant from Valio Ltd., Finland. The Wihuri Research Institute is maintained by the Jenny and Antti Wihuri Foundation in Helsinki, Finland.

\section{References}

1 Kuoppala A, Shiota N, Lindstedt KA, Rysä J, Leskinen HK, Luodonpää M, Liesmaa I, Ruskoaho H, Kaaja R, Kovanen PT, Kokkonen JO: Expression of bradykinin receptors in the left ventricles of rats with pressure overload hypertrophy and heart failure. J Hypertens 2003;21:1729-1736.

-2 Vapaatalo H, Mervaala E, Nurminen ML: Role of endothelium and nitric oxide in experimental hypertension. Physiol Res 2000; 49:1-10.

- 3 Brooks BA, Franjic B, Ban CR, Swaraj K, Yue DK, Celermajer DS, Twigg SM: Diastolic dysfunction and abnormalities of the microcirculation in type 2 diabetes. Diabetes Obes Metab 2008;10:739-746.
-4 Jin SM, Noh CI, Yang SW, Bae EJ, Shin CH, Chung HR, Kim YY, Yun YS: Endothelial dysfunction and microvascular complications in type 1 diabetes mellitus. J Korean Med Sci 2008;23:77-82.

5 Mohri M, Takeshita A: Coronary microvascular disease in humans. Jpn Heart J 1999;40: 97-108.

-6 Neglia D, L'Abbate A: Coronary microvascular dysfunction and idiopathic dilated cardiomyopathy. Pharmacol Rep 2005;57:151155.

7 Marijianowski MM, van Laar M, Bras J, Becker AE: Chronic congestive heart failure is associated with a phenotypic shift of intramyocardial endothelial cells. Circulation 1995;92:1494-1498.
-8 Tanaka M, Fujiwara H, Onodera T, Wu DJ, Matsuda M, Hamashima Y, Kawai C: Quantitative analysis of narrowings of intramyocardial small arteries in normal hearts, hypertensive hearts, and hearts with hypertrophic cardiomyopathy. Circulation 1987;75: $1130-1139$

-9 Gryglewski RJ, Uracz W, Chlopicki S, Marcinkiewicz E: Bradykinin as a major endogenous regulator of endothelial function. Pediatr Pathol Mol Med 2002;21:279-290.

10 Oeseburg H, Iusuf D, van der Harst P, van Gilst WH, Henning RH, Roks AJ: Bradykinin protects against oxidative stress-induced endothelial cell senescence. Hypertension 2009;53:417-422. 
-11 Kakoki M, Kizer CM, Yi X, Takahashi N, 25 Li HJ, Yin H, Yao YY, Shen B, Bader M, Chao Kim HS, Bagnell CR, Edgell CJ, Maeda N, Jennette JC, Smithies O: Senescence-associated phenotypes in Akita diabetic mice are enhanced by absence of bradykinin $\mathrm{B}_{2}$ receptors. J Clin Invest 2006;116:1302-1309.

-12 Maestri R, Milia AF, Salis MB, Graiani G, Lagrasta C, Monica M, Corradi D, Emanueli C, Madeddu P: Cardiac hypertrophy and microvascular deficit in kinin $\mathrm{B}_{2}$ receptor knockout mice. Hypertension 2003;41:11511155.

-13 Emanueli C, Maestri R, Corradi D, Marchione R, Minasi A, Tozzi MG, Salis MB, Straino S, Capogrossi MC, Olivetti G, Madeddu P: Dilated and failing cardiomyopathy in bradykinin $\mathrm{B}_{2}$ receptor knockout mice. Circulation 1999;100:2359-2365.

-14 Anversa P, Hiler B, Ricci R, Guideri G, Olivetti G: Myocyte cell loss and myocyte hypertrophy in the aging rat heart. J Am Coll Cardiol 1986;8:1441-1448.

15 Sadoun E, Reed MJ: Impaired angiogenesis in aging is associated with alterations in vessel density, matrix composition, inflammatory response, and growth factor expression. J Histochem Cytochem 2003;51:1119-1130.

-16 Kumazaki T, Wadhwa R, Kaul SC, Mitsui Y: Expression of endothelin, fibronectin, and mortalin as aging and mortality markers. Exp Gerontol 1997;32:95-103.

-17 Heikkilä HM, Lätti S, Leskinen MJ, Hakala JK, Kovanen PT, Lindstedt KA: Activated mast cells induce endothelial cell apoptosis by a combined action of chymase and tumor necrosis factor- $\alpha$. Arterioscler Thromb Vasc Biol 2008;28:309-314.

- 18 Nishida M, Carley WW, Gerritsen ME, Ellingsen O, Kelly RA, Smith TW: Isolation and characterization of human and rat cardiac microvascular endothelial cells. Am J Physiol 1993;264:H639-H652.

-19 Dimri GP, Lee X, Basile G, Acosta M, Scott G, Roskelley C, Medrano EE, Linskens M, Rubelj I, Pereira-Smith O: A biomarker that identifies senescent human cells in culture and in aging skin in vivo. Proc Natl Acad Sci USA 1995;92:9363-9367.

-20 Lee HC, Yin PH, Lu CY, Chi CW, Wei YH: Increase of mitochondria and mitochondrial DNA in response to oxidative stress in human cells. Biochem J 2000;348:425-432.

$\checkmark 21$ Boels K, Schaller HC: Identification and characterisation of GPR100 as a novel human G-protein-coupled bradykinin receptor. Br J Pharmacol 2003;140:932-938.

22 Touyz RM, Briones AM: Reactive oxygen species and vascular biology: implications in human hypertension. Hypertens Res +2011 ; $34: 5-14$.

23 Cosentino F, Osto E: Aging and endothelial dysfunction. Clin Hemorheol Microcirc. 2007;37:143-147.

-24 Gates PE, Strain WD, Shore AC: Human endothelial function and microvascular ageing. Exp Physiol 2009;94:311-316.
L, Chao J: Tissue kallikrein protects agains pressure overload-induced cardiac hypertrophy through kinin $\mathrm{B}_{2}$ receptor and glycogen synthase kinase- $3 \beta$ activation. Cardiovasc Res 2007;73:130-142.

26 Linz W, Wiemer G, Scholkens BA: Cardioprotective actions of bradykinin in myocardial ischemia and left ventricular hypertrophy. Braz J Med Biol Res 1994;27:1949-1954.

27 Venema RC: Post-translational mechanisms of endothelial nitric oxide synthase regulation by bradykinin. Int Immunopharmacol 2002;2:1755-1762.

28 Clementi E, Brown GC, Foxwell N, Moncada $\mathrm{S}$ : On the mechanism by which vascular endothelial cells regulate their oxygen consumption. Proc Natl Acad Sci USA 1999;96: 1559-1562.

29 Higaki T, Sawada S, Kono Y, Imamura H, Tada Y, Yamasaki S, Toratani A, Sato T, Komatsu S, Akamatsu N, Tamagaki T, Tsuda Y, Tsuji H, Nakagawa M: A role of protein kinase $\mathrm{C}$ in the regulation of cytosolic phospholipase $\mathrm{A}_{2}$ in bradykinin-induced $\mathrm{PGI}_{2}$ synthesis by human vascular endothelial cells. Microvasc Res 1999;58:144-155.

30 Archer SL, Gragasin FS, Wu X, Wang S, McMurtry S, Kim DH, Platonov M, Koshal A, Hashimoto K, Campbell WB, Falck JR, Michelakis ED: Endothelium-derived hyperpolarizing factor in human internal mammary artery is 11,12-epoxyeicosatrienoic acid and causes relaxation by activating smooth muscle $\mathrm{BK}_{\mathrm{Ca}}$ channels. Circulation 2003;107: 769-776.

31 Wang X, Trottier G, Loutzenhiser R: Determinants of renal afferent arteriolar actions of bradykinin: evidence that multiple pathways mediate responses attributed to EDHF. Am Physiol Renal Physiol 2003;285:F540-F549.

32 Chiaratti MR, Meirelles FV: Increase in mitochondrial DNA quantity and impairment of oxidative phosphorylation in bovine fibroblast cells treated with ethidium bromide for 15 passages in culture. Genet Mol Res 2006;5:55-62.

33 Lee CF, Liu CY, Hsieh RH, Wei YH: Oxidative stress-induced depolymerization of microtubules and alteration of mitochondrial mass in human cells. Ann NY Acad Sci 2005; 1042:246-254

34 Lee HC, Wei YH: Mitochondrial biogenesis and mitochondrial DNA maintenance of mammalian cells under oxidative stress. Int J Biochem Cell Biol 2005;37:822-834.

35 Muller FL, Lustgarten MS, Jang Y, Richardson A, Van Remmen H: Trends in oxidative aging theories. Free Radic Biol Med 2007;43: 477-503.

36 Unterluggauer H, Hampel B, Zwerschke W, Jansen-Durr P: Senescence-associated cell death of human endothelial cells: the role of oxidative stress. Exp Gerontol 2003;38:11491160 .
37 van der Loo B, Labugger R, Skepper JN, Bachschmid M, Kilo J, Powell JM, PalaciosCallender M, Erusalimsky JD, Quaschning T, Malinski T, Gygi D, Ullrich V, Luscher TF: Enhanced peroxynitrite formation is associated with vascular aging. J Exp Med 2000; 192:1731-1744.

-38 Rodriguez-Manas L, El-Assar M, Vallejo S, Lopez-Doriga P, Solis J, Petidier R, Montes M, Nevado J, Castro M, Gomez-Guerrero C, Peiro C, Sanchez-Ferrer CF: Endothelial dysfunction in aged humans is related with oxidative stress and vascular inflammation. Aging Cell 2009;8:226-238.

-39 Kaiser D, Freyberg MA, Friedl P: Lack of hemodynamic forces triggers apoptosis in vascular endothelial cells. Biochem Biophys Res Commun 1997;231:586-590.

40 Liu WF, Nelson CM, Tan JL, Chen CS: Cadherins, RhoA, and Rac1 are differentially required for stretch-mediated proliferation in endothelial versus smooth muscle cells. Circ Res 2007;101:e44-e52.

41 Thorin E, Thorin-Trescases N: Vascular endothelial ageing, heartbeat after heartbeat. Cardiovasc Res 2009;84:24-32.

$\checkmark 42$ Pieske B, Wachter R: Impact of diabetes and hypertension on the heart. Curr Opin Cardiol 2008;23:340-349.

43 Munk VC, Sanchez de Miguel L, Petrimpol M, Butz N, Banfi A, Eriksson U, Hein L, Humar R, Battegay EJ: Angiotensin II induces angiogenesis in the hypoxic adult mouse heart in vitro through an $\mathrm{AT}_{2}-\mathrm{B}_{2}$ receptor pathway. Hypertension 2007;49:1178-1185.

44 Sanchez de Miguel L, Neysari S, Jakob S, Petrimpol M, Butz N, Banfi A, Zaugg CE, Humar R, Battegay EJ: $\mathrm{B}_{2}$-kinin receptor plays a key role in $\mathrm{B}_{1^{-}}$, angiotensin converting enzyme inhibitor-, and vascular endothelial growth factor-stimulated in vitro angiogenesis in the hypoxic mouse heart. Cardiovasc Res 2008;80:106-113.

45 Parenti A, Morbidelli L, Ledda F, Granger $\mathrm{HJ}$, Ziche M: The bradykinin/B1 receptor promotes angiogenesis by up-regulation of endogenous FGF-2 in endothelium via the nitric oxide synthase pathway. FASEB J 2001;15:1487-1489.

-46 Rivard A, Fabre JE, Silver M, Chen D, Murohara T, Kearney M, Magner M, Asahara T, Isner JM: Age-dependent impairment of angiogenesis. Circulation 1999;99:111-120.

47 Zhang Y, Pan KH, Cohen SN: Senescencespecific gene expression fingerprints reveal cell-type-dependent physical clustering of up-regulated chromosomal loci. Proc Natl Acad Sci USA 2003;100:3251-3256.

$\checkmark 48$ Sano M, Minamino T, Toko H, Miyauchi H, Orimo M, Qin Y, Akazawa $\mathrm{H}$, Tateno $\mathrm{K}$, Kayama Y, Harada M, Shimizu I, Asahara T, Hamada H, Tomita S, Molkentin JD, Zou Y, Komuro I: p53-induced inhibition of Hif-1 causes cardiac dysfunction during pressure overload. Nature 2007;446:444-448. 
49 Kunieda T, Minamino T, Nishi J, Tateno K, Oyama T, Katsuno T, Miyauchi H, Orimo M, Okada S, Takamura M, Nagai T, Kaneko S, Komuro I: Angiotensin II induces premature senescence of vascular smooth muscle cells and accelerates the development of atherosclerosis via a p21-dependent pathway. Circulation 2006;114:953-960.

-50 Shen B, Harrison-Bernard LM, Fuller AJ, Vanderpool V, Saifudeen Z, El-Dahr SS: The bradykinin B2 receptor gene is a target of angiotensin II type 1 receptor signaling. J Am Soc Nephrol. 2007;18:1140-1149.

-51 Marks J, Saifudeen Z, Dipp S, El-Dahr SS: Two functionally divergent p53-responsive elements in the rat bradykinin $\mathrm{B} 2$ receptor promoter. J Biol Chem 2003;278:3415834166.
52 Meini S, Bellucci F, Cucchi P, Giuliani S, Quartara L, Giolitti A, Zappitelli S, Rotondaro L, Boels K, Maggi CA: Bradykinin B2 and GPR100 receptors: a paradigm for receptor signal transduction pharmacology. Br J Pharmacol 2004;143:938-941.

53 Marceau F, Larrivee JF, Bouthillier J, Bachvarova $\mathrm{M}$, Houle S, Bachvarov DR: Effect of endogenous kinins, prostanoids, and $\mathrm{NO}$ on kinin B1 and B2 receptor expression in the rabbit. Am J Physiol 1999;277:R1568-R1578.

54 Linz W, Wiemer G, Scholkens BA: Contribution of bradykinin to the cardiovascular effects of ramipril. J Cardiovasc Pharmacol 1993;22:S1-S8.
55 Liu C, Chen J, Sutton S, Roland B, Kuei C, Farmer N, Sillard R, Lovenberg TW: Identification of relaxin-3/INSL7 as a ligand for GPCR142. J Biol Chem 2003;278:5076550770.

56 Chen J, Kuei C, Sutton SW, Bonaventure P, Nepomuceno D, Eriste E, Sillard R, Lovenberg TW, Liu C: Pharmacological characterization of relaxin-3/INSL7 receptors GPCR135 and GPCR142 from different mammalian species. J Pharmacol Exp Ther 2005;312:83-95.

57 Dschietzig T, Richter C, Bartsch C, Laule M, Armbruster FP, Baumann G, Stangl K: The pregnancy hormone relaxin is a player in human heart failure. FASEB J 2001;15:21872195 . 